\title{
DOES SENTIMENT AFFECT CAPITAL STRUCTURE DECISIONS?
}

\author{
DOI: 10.17261/Pressacademia.2018.994 \\ JBEF- V.7-ISS.4-2018(3)-p.340-345
}

\section{Efe Caglar Cagli ${ }^{1}$, Elif Korkmaz², M. Banu Durukan ${ }^{3}$}

${ }^{1}$ Dokuz Eylül University, Faculty of Business, Department of Business Administration, Tınaztepe Campus, Izmir, Turkey. efe.cagli@deu.edu.tr, ORCID: 0000-0002-8250-141X

${ }^{2}$ Dokuz Eylül University, Faculty of Business, Department of Business Administration, Tınaztepe Campus, Izmir, Turkey. elif.korkmaz@deu.edu.tr, ORCID: 0000-0002-0298-3296

${ }^{3}$ Dokuz Eylül University, Faculty of Business, Department of Business Administration, Tınaztepe Campus, Izmir, Turkey. banu.durukan@deu.edu.tr, ORCID: 0000-0002-3619-2732

Date Received: October 27, 2018

Date Accepted: December 22, 2018

To cite this document

To cite this document

Cagli, E. C., Korkmaz, E., Durukan, M. B. (2018). Does sentiment affect capital structure decisions?. Journal of Business, Economics and Finance (JBEF), V.7(4), p.340-345.

Permanent link to this document: $\underline{\text { http://doi.org/10.17261/Pressacademia.2018.994 }}$

Copyright: Published by PressAcademia and limited licensed re-use rights only.

\begin{abstract}
Purpose- This study aims to investigate whether investor and managerial sentiment have an effect on capital structure decisions of manufacturing firms listed on Borsa Istanbul between 2010 and 2017. This study contributes to the existing literature by including sentiment as a determinant of capital structure in the analysis as well as differentiating between investor and managerial sentiment.

Methodology- To test for the relationship, Consumer Confidence Index and Real Sector Confidence Index are used to proxy for investor sentiment and managerial sentiment, respectively. Quarterly financial statements of manufacturing firms are used to collect firm specific and capital structure data for the period from 2010 to 2017. Panel data framework is employed to analyze the relationship between firm specific variables and sentiment, and leverage level of the firms.

Findings- Statistically significant negative relationship is determined between investor sentiment and total leverage; and managerial sentiment and total leverage of the firms at $1 \%$ level. Hence, when sentiment goes up, representing optimism, debt level of firms goes down.

Conclusion- Our findings may be explained by the Market Timing Theory which argues that equity financing is preferred by managers when the stocks of the firm are overvalued on the market. Hence, when the market has an optimistic view, measured by investor sentiment, the firms have higher levels of equity financing which lends support to this argument. The findings also support the claim that individual perceptions are influential in the decision-making process. Managers as individuals, also prefer equity financing when they are optimistic, proxied by managerial sentiment.
\end{abstract}

Keywords: Capital structure, investor sentiment, managerial sentiment, market timing, behavioral finance.

JEL Codes: G32, G40, C23

\section{INTRODUCTION}

The capital structure decision still remains a puzzle for the finance researchers. Since Modigliani and Miller (1958) put forward the Irrelevance Theory of Capital Structure, many other theories, such as the Trade-off Theory, Pecking Order Theory and Market Timing Theory are developed and tested in various markets. Even though, the evidence provided by the capital structure research has been inconclusive (HaKilicrris and Raviv, 1991, Myers, 2003), pecking order theory seems to dominate as stated by Kumar and Colombage (2017).

On the other hand, the Market Timing Theory questions the market efficiency assumptions of the Pecking Order Theory and the Trade-off Theory. It argues that managers seek for windows of opportunity and issue equity, given their financing needs, when they believe that the firm's stock is mispriced, specifically overvalued. If the market undervalues the stock, the managers prefer 
debt financing. Baker and Wurgler (2002), Alti (2004), Hovakimian (2004), and Kayhan and Titman (2007) provide supporting evidence for Market Timing Theory.

In search of explanations for the capital structure choice of companies, there is extensive research focusing on the factors, firmspecific or country-specific that determine capital structure. Jong, Kabir, and Nguyen (2008), in their multi-country analysis, conclude that firm-specific factors of capital structure vary between different countries and country specific factors also play an important role through their influence on firm specific factors. Consequently, the finance literature mainly investigates the effect of firm size, profitability, tangibility of the firm's asset, growth opportunities of the firm, taxes and non-debt tax shield as firm-specific factors, and gross domestic product, inflation and financial market development level as country specific factors on capital structure choice.

In addition to the firm specific and country specific factors, approaching the arguments of Market Timing Theory from a behavioral perspective, it can be argued that capital structure decisions should also be affected by the managers' and investors' confidence in the market. Hence sentiment, defined as pessimism or optimism of investors (Baker and Wurgler, 2006:1649), can be used as a measure of confidence. That is if optimism exists in the market, the stock prices will go up leading to overvaluation of equities, which may in return lead managers to choose equity financing. Hence the managers will be acting according to the market timing theory or windows of opportunity hypothesis (Ritter, 1991; Loughran and Ritter, 1995).

In line with the above explanations this study aims to contribute to the literature by investigating whether investor and managerial sentiment have an impact on capital structure decisions of manufacturing firms listed on Borsa Istanbul between 2010 and 2017. Moreover, different than previous studies, sentiment is analyzed from the investors' and managers' points of view distinctively. Investor sentiment proxied by the Consumer Confidence Index $(C C l)$ to measure the optimism in the market in general and managerial sentiment by the Real Sector Confidence Index $(R S I)$ to measure the optimism of the managers regarding the market are analyzed in order to shed light on their possible effects on capital structure choice.

The rest of the study is structured as follows: In the second part studies on capital structure, sentiment measures and their relationship are reviewed. Data and methodology are explained in the succeeding part, followed by the presentation and discussion of empirical findings. The last part concludes.

\section{LITERATURE REVIEW}

The research on capital structure has concentrated around two theories, namely the Trade-off theory and Pecking Order Theory. Trade-off theory states that there is an optimal capital structure where the benefits and costs of debt are balanced. Debt has tax benefits (Miller and Modigliani, 1963; Miller, 1977) as well limiting the agency costs of free cash flows (Jensen, 1986). However, debt financing also has bankruptcy costs. The Pecking Order Theory, on the other hand, argues that because of information asymmetries and the investors' reaction to stock issues, the managers prefer new equity issue as a last resort (Myers, 1984; Myers and Majluf, 1984). However, as Fama and French (2005) conclude both theories have drawbacks as well as plausible explanations for capital structure decisions. Market timing theory on the other hand argues that firms will prefer equity financing when their stock is overvalued. In other words, managers will take advantage of hot markets and issue new equity (Baker and Wurgler, 2002; Bayles and Chaplinsky, 1996).

Many studies aiming to test the above-mentioned theories have empirically examined firm-specific and country-specific factors that determine capital structure (Jong, Kabir, and Nguyen, 2008; Titman and Wessels, 1988). Firm size, profitability, tangibility of the firm's assets, growth opportunities, taxes and non-debt tax shield as firm-specific factors and gross domestic product, inflation and financial market development level as country specific factors are mainly investigated. Corporate governance related factors such as the board structure and ownership structure are included in the analysis.

To test for the Market Timing Theory of capital structure, effect of sentiment on capital structure should be investigated. Since sentiment is defined as pessimism or optimism of investors related with financial markets (Baker and Wurgler, 2006: 1649), it reflects hot markets when there is optimism. Shefrin (2008:216) asserts that sentiment is optimism regarding financial market conditions and similarly Statman et al (2008: 20) describe it as the thoughts and perceptions of investors regarding financial market conditions. Consequently, it can be argued that when investor sentiment is high, that is, there is optimism in the market, managers will prefer equity financing.

Moreover, it is documented by Bilgehan (2014), Mefteh and Oliver (2010), Oliver (2005) that the managers' biases also affect their choice of financing decisions. The manager's confidence in the market or himself must be distinguished. Majority of the studies focus on managerial overconfidence in their abilities and hence argue that there is a positive relationship between 
managerial confidence and debt financing (Bilgehan, 2014). However, if the managers' perception of the market is taken into consideration, the relationship must be negative following the market timing theory. That is, if the managers are optimistic about the market conditions, that is if managerial sentiment is high, then they should prefer equity financing.

A variety of measures is used for sentiment in the literature. These include direct measures such as confidence or sentiment surveys, and indirect measures such as closed end fund discount, stock market transaction volume, first day returns of initial public offerings, fund flow of mutual funds and internet searches. Moreover, Baker and Wurgler (2006) suggest using a composite sentiment index which they argue reflects sentiment better than the indirect measures.

Since the aim of the present study is also to distinguish between the impacts of managerial and investor sentiment on capital structure choice, direct measurement will be preferred. As a proxy for investor sentiment, Consumer Confidence Index (CCI) and for managerial sentiment Real Sector Confidence Index (RSI) calculated by the Central Bank of the Republic of Turkey (CBRT) and Turkish Statistical Institute (TURKSTAT) are used. $C C I$ is calculated based on survey data from consumers whereas $R S I$ is calculated based on survey data from managers. Therefore, including these as proxies of investor sentiment and managerial sentiment in the analysis will make it possible to distinguish between the two types of sentiment.

\section{DATA AND METHODOLOGY}

\subsection{Data}

We obtain firm-level data from the FINNET database. Our sample consists of 169 non-financial firms listed on Borsa Istanbul after we drop the financials and the firms with interrupted data. We collect three leverage measures, total leverage, long-term leverage, and short-term leverage. We also obtain firm-specific data measuring size, profitability, tangibility of assets, taxes paid by the firms and growth opportunities of the firms.

Sentiment and macroeconomic indicators are obtained from the Central Bank of the Republic of Turkey (CBRT) and Turkish Statistical Institute (TURKSTAT). Consumer Confidence Index $(C C I)$ and Real Sector Confidence Index (RSI) are used as proxies for investor sentiment and managerial sentiment, respectively. $C C l$ is calculated according to participants' answers to the questions related with their current opinions and expectations about general economic conditions and their personal financial conditions. $R S I$ is an indicator that aims to show the impressions of real sector representatives about the general situation of the Turkish economy. We include Consumer Price Index as a macroeconomic indicator in the analysis.

We analyze quarterly data over the period 2010Q1 - 2017Q4. Table 1 reports the definition of the variables used in the analysis along with summary statistics.

Table 1: Definition of Variables and Summary Statistics

\begin{tabular}{|c|c|c|c|c|}
\hline Name & Acronym & Definition/Calculation & Mean & Std. Dev. \\
\hline \multicolumn{5}{|c|}{ a. Leverage Measures } \\
\hline Total Leverage & $T L V$ & Total Debt $\div$ Total Assets & 0.525 & 0.476 \\
\hline Long Term Leverage & $L L V$ & Long Term Debt $\div$ Total Assets & 0.150 & 0.170 \\
\hline Short Term Leverage & $S L V$ & Short Term Debt $\div$ Total Assets & 0.375 & 0.426 \\
\hline \multicolumn{5}{|c|}{ b. Firm-Specific Factors } \\
\hline Size & SZE & Natural Logarithm of Sales & 18.915 & 2.150 \\
\hline Profitability & $P R F$ & EBITDA $\div$ Total Assets & 0.059 & 0.070 \\
\hline Tangibility & TNG & Plant Property Equipment $\div$ Total Assets & 0.481 & 0.219 \\
\hline Tax & TAX & Tax Paid $\div$ EBT & -0.358 & 32.396 \\
\hline Growth Opportunities & MTB & Market Value $\div$ Book Value & 2.401 & 5.136 \\
\hline \multicolumn{5}{|c|}{ c. Sentiment and Macroeconomic Indicators } \\
\hline Investor Sentiment & $\mathrm{CCl}$ & Change in Consumer Confidence Index & 0.002 & 0.047 \\
\hline Managerial Sentiment & $R S I$ & Change in Real Sector Confidence Index & 0.005 & 0.026 \\
\hline Consumer Price Index & $C P I$ & Change in Consumer Price Index & 0.021 & 0.013 \\
\hline
\end{tabular}

\subsection{Methodology}

We estimate the following panel-data models using Generalized Least Squares (GLS) to examine the relationship between each of the leverage measures and the sentiment indicators: 
$y_{i t}=\alpha+\beta_{1} C C_{i t}+\beta_{2} \mathbf{x}_{i t}+\varepsilon_{i t}$

$y_{i t}=\alpha+\beta_{1} R S I_{i t}+\beta_{2} \mathbf{X}_{i t}+\varepsilon_{i t}$

where $y_{i t}$ is one of the leverage measures (i.e. TLV, LLV, SLV) and $\mathbf{x}_{i t}=\left(S Z E_{i t}, P R F_{i t}, T N G_{i t}, M T B_{i t}, T A X_{i t}, C P I_{i t}\right)^{\prime}$ is the vector of firmspecific and macroeconomic variables, $C C l_{i t}$ and $R S I_{i t}$ are the investor and managerial sentiment indicators, respectively, and $\varepsilon$ is the error term. For each of the six panel-data models specified above, we calculate the Hausman test statistics for testing the null hypothesis of random effects against the alternative hypothesis of fixed effects.

\section{FINDINGS AND DISCUSSIONS}

Table 2 reports the estimation results for the panel data models specified in Equations (1) and (2). $p$-values of Hausman test statistics are estimated higher than the conventional statistical significance levels, suggesting using random effects specification for all specified models. For all estimated models, we reject the null hypothesis that all coefficients in the model are zero at the $1 \%$ level based on the $p$-values of $\chi^{2}$ statistics, $p$ - $\chi^{2}$, reported in Table 2 .

Table 2 shows that $C C I$ and $R S I$ have significant negative impact on $T L V$ at the $1 \%$ significance level. The parameter estimates of $\mathrm{CCl}$ and $\mathrm{RSI}$ are not statistically significant at conventional levels in the other models, suggesting that none of the sentiment indicators $(C C l$ and $R S I)$ has an impact on each of the other leverage measures, $L L V$ and $S L V$. These results are consistent with the Market Timing Theory and imply that the higher the optimism about the market, lower the debt level.

Table 2: Random GLS regression Results

\begin{tabular}{|c|c|c|c|c|c|c|}
\hline \multirow[b]{2}{*}{ Independent Variable } & \multicolumn{6}{|c|}{ Dependent Variable } \\
\hline & $\overline{T L V}$ & LLV & SLV & TLV & LLV & SLV \\
\hline$\alpha$ & $\begin{array}{l}-0.433^{a} \\
(0.004)\end{array}$ & $\begin{array}{l}-0.369^{a} \\
(0.000)\end{array}$ & $\begin{array}{l}-0.028 \\
(0.801)\end{array}$ & $\begin{array}{l}-0.442^{b} \\
(0.003)\end{array}$ & $\begin{array}{l}-0.372^{a} \\
(0.000)\end{array}$ & $\begin{array}{l}-0.335 \\
(0.765)\end{array}$ \\
\hline $\mathrm{CCl}$ & $\begin{array}{l}-0.083^{a} \\
(0.010)\end{array}$ & $\begin{array}{l}-0.330 \\
(0.275)\end{array}$ & $\begin{array}{l}-0.051 \\
(0.301)\end{array}$ & - & - & - \\
\hline$R S I$ & - & - & - & $\begin{array}{l}-0.260^{a} \\
(0.008)\end{array}$ & $\begin{array}{l}-0.366 \\
(0.674)\end{array}$ & $\begin{array}{l}-0.222 \\
(0.186)\end{array}$ \\
\hline SZE & $\begin{array}{l}0.0485^{a} \\
(0.000)\end{array}$ & $\begin{array}{l}0.022^{a} \\
(0.000)\end{array}$ & $\begin{array}{l}0.024^{a} \\
(0.000)\end{array}$ & $\begin{array}{l}0.0488^{a} \\
(0.000)\end{array}$ & $\begin{array}{l}0.224^{a} \\
(0.000)\end{array}$ & $\begin{array}{l}0.249^{a} \\
(0.000)\end{array}$ \\
\hline$P R F$ & $\begin{array}{l}-0.8242^{a} \\
(0.001)\end{array}$ & $\begin{array}{l}-0.227^{a} \\
(0.000)\end{array}$ & $\begin{array}{l}-0.584^{a} \\
(0.002)\end{array}$ & $\begin{array}{l}-0.8211^{a} \\
(0.001)\end{array}$ & $\begin{array}{l}-0.226^{a} \\
(0.000)\end{array}$ & $\begin{array}{l}-0.582^{a} \\
(0.002)\end{array}$ \\
\hline$T N G$ & $\begin{array}{l}0.149 \\
(0.169)\end{array}$ & $\begin{array}{l}0.218^{a} \\
(0.000)\end{array}$ & $\begin{array}{l}-0.084 \\
(0.333)\end{array}$ & $\begin{array}{l}0.152 \\
(0.162)\end{array}$ & $\begin{array}{l}0.219^{a} \\
(0.000)\end{array}$ & $\begin{array}{l}-0.081 \\
(0.354)\end{array}$ \\
\hline MTB & $\begin{array}{l}0.003^{c} \\
(0.062)\end{array}$ & $\begin{array}{l}0.000 \\
(0.560)\end{array}$ & $\begin{array}{l}0.003^{c} \\
(0.064)\end{array}$ & $\begin{array}{l}0.003^{c} \\
(0.062)\end{array}$ & $\begin{array}{l}0.000 \\
(0.564)\end{array}$ & $\begin{array}{l}0.003^{c} \\
(0.064)\end{array}$ \\
\hline TAX & $\begin{array}{l}0.000^{b} \\
(0.012)\end{array}$ & $\begin{array}{l}0.000 \\
(0.644)\end{array}$ & $\begin{array}{l}0.000^{a} \\
(0.010)\end{array}$ & $\begin{array}{l}0.000^{c} \\
(0.057)\end{array}$ & $\begin{array}{l}0.000 \\
(0.820)\end{array}$ & $\begin{array}{l}0.000^{c} \\
(0.055)\end{array}$ \\
\hline$C P I$ & $\begin{array}{l}0.346 \text { a } \\
(0.003)\end{array}$ & $\begin{array}{l}0.254^{a} \\
(0.000)\end{array}$ & $\begin{array}{l}0.093 \\
(0.349)\end{array}$ & $\begin{array}{l}0.440 \mathrm{a} \\
(0.000)\end{array}$ & $\begin{array}{l}0.269 \mathrm{a} \\
(0.000)\end{array}$ & $\begin{array}{l}0.172^{b} \\
(0.036)\end{array}$ \\
\hline \multicolumn{7}{|l|}{ Summary Statistics } \\
\hline$\sigma_{u}$ & 0.431 & 0.123 & 0.345 & 0.431 & 0.123 & 0.345 \\
\hline$\sigma_{e}$ & 0.201 & 0.102 & 0.237 & 0.201 & 0.102 & 0.237 \\
\hline$\rho$ & 0.820 & 0.593 & 0.678 & 0.820 & 0.592 & 0.678 \\
\hline$p-\left(\chi^{2}\right)$ & 0.000 & 0.000 & 0.000 & 0.000 & 0.000 & 0.000 \\
\hline$R^{2}$ - within & 0.055 & 0.051 & 0.019 & 0.056 & 0.051 & 0.020 \\
\hline$R^{2}$ - between & 0.003 & 0.160 & 0.016 & 0.003 & 0.160 & 0.015 \\
\hline$R^{2}$ - overall & 0.008 & 0.120 & 0.017 & 0.008 & 0.120 & 0.016 \\
\hline$p-B P$ & 0.000 & 0.000 & 0.000 & 0.000 & 0.000 & 0.000 \\
\hline$p-$ Hausman & 0.483 & 0.587 & 0.188 & 0.431 & 0.123 & 0.345 \\
\hline
\end{tabular}


Note: $a, b$, and c indicate statistical significance at $1 \%, 5 \%$ and $10 \%$ level, respectively. The numbers in parentheses are standard errors of the parameter estimates. $\rho$ is the interclass correlation and is calculated by dividing $\sigma^{2}{ }_{u}$ by sum of $\sigma_{u}$ and $\sigma_{e}$. (where $\sigma_{u}$ and $\sigma_{e}$ are standard deviation of residuals within groups $\left(u_{i}\right)$ and standard deviation of overall error term $\left(e_{i}\right)$ ). $p-\left(\chi^{2}\right)$ is the $p$-value of the test statistic for the null hypothesis that all coefficients in the model are zero. $R^{2}$ - within, $R^{2}$ - between, and $R^{2}$ - overall are the coefficients of determination for within the groups, between the groups, and overall, respectively. $p-B P$ is the $p$-value of the Breusch and Pagan (1980) Lagrange multiplier (LM) test for the null hypothesis that variances across groups are zero. It also shows that random effects model is appropriate. $p-$ Hausman is the $p$-value of Hausman (1978) test for the null hypothesis of random model is appropriate.

The parameter estimates of SZE (PRF) in the models are found to be positive (negative) and statistically significant at the $1 \%$ level. The positive (negative) sign of the SZE (PRF) estimates suggests that firm size (profitability) has a positive (negative) impact on the leverage regardless of the maturity, consistent with the Trade-off Theory (Pecking Order Theory). TNG has only significant and positive impact on $L L V$ at the $1 \%$ level, consistent with both the Trade-off Theory and Pecking Order Theory. MTB and TAX have positive and significant relationships with $T L V$ and SLV at the conventional significance levels. While our findings related to MTB are consistent with the Pecking Order Theory, the results for TAX are in accordance with the Trade-off Theory. $C P I$ is found to have a positive and significant impact on $T L V$ and $L L V$ at the $1 \%$ level, which is in line with the Trade-off Theory. The relationship between $C P I$ and $S L V$ is only significant in the model with $R S I$ at the $5 \%$ level.

\section{CONCLUSION}

The search for the explanation of capital structure choice still continues. Researchers have developed theories that try to explain how the firms make their financing choices. The Trade-off Theory, Pecking Order Theory and Market Timing Theory are the three main theories that are researched most commonly. However, none of them can provide an answer by itself and they all have drawbacks.

The determinants of capital structure are investigated based on the arguments of the above-mentioned theories. Firm-specific and country-specific factors are tested in one country or multi-country contexts. The present study added sentiment as another determinant of capital structure based on the market timing theory. Since the market timing theory argues that the managers prefer equity financing during hot markets, sentiment may proxy for the perception of the investors and manager of the market conditions. Hence this study aimed to contribute to the literature by investigating whether investor and managerial sentiment have an impact on capital structure decisions of manufacturing firms listed on Borsa Istanbul between 2010 and 2017. Moreover, different than previous studies, sentiment is analyzed from the investors' and managers' points of view distinctively. Investor sentiment proxied by the $C C I$ to measure the optimism in the market in general and managerial sentiment by the $R S I$ to measure the optimism of the managers regarding the market are analyzed in order to shed light on their possible effects on capital structure.

The empirical findings show that $C C I$ and $R S I$ have statistically significant negative effect on total leverage of the firms. The results for total leverage are consistent with the Market Timing Theory implying that when the investors' as well as managers' sentiment goes up, the preferred financing is equity financing. Stated differently, when there is optimism in the market or when the managers are optimistic about market conditions, then to take advantage of this equity is preferred. However, the same relationship did not sustain for short-term or long-term leverage. Hence this needs further investigation. The present study also provided evidence on the relationship of other determinants with capital structure. The evidence was mixed supporting the Trade-off Theory for some and Pecking Order Theory for the others which provides support to the argument that these theories are complementary rather than supplementary.

In sum, the statistically significant relationship found for investor sentiment and managerial sentiment is consistent with Market Timing Theory. The findings also support the claim that individual perceptions are influential in the decision-making process. The study contributed to the literature by using two separate measures to distinguish between investor and managerial sentiment as well as including sentiment as a determinant in the analysis.

\section{REFERENCES}

Alti, A. (2006). How persistent is the impact of market timing on capital structure?. The Journal of Finance, 61(4), 1681-1710. DOI: 10.1111/j.1540-6261.2006.00886.x

Baker, M., Wurgler, J. (2002). Market Timing and Capital Structure. The Journal of Finance, 57(1), 1-32. DOI: 10.1111/1540-6261.00414

Baker, M., Wurgler, J. (2006). Investor sentiment and the cross-section of stock returns. The journal of Finance, 61(4), 1645-1680. DOI: $10.1111 / \mathrm{j} .1540-6261.2006 .00885 . x$ 
Bayless, M., Chaplinsky, S. (1996). Is there a window of opportunity for seasoned equity issuance?. The Journal of Finance, 51(1), 253-278. DOI: 10.1111/j.1540-6261.1996.tb05209.x

Bilgehan, T. (2014). Psychological biases and the capital structure decisions: a literature review. Theoretical and Applied Economics, 12(601), 123-142.

Breusch, T., Pagan, A. (1980). The lagrange multiplier test and its applications to model specification in econometrics. The Review of Economic Studies, 47(1), 239-253. DOI: 10.2307/2297111

Central Bank of the Republic of Turkey. Retrieved 2018, June 11 from https://evds2.tcmb.gov.tr/index.php?/evds/serieMarket

De Jong, A., Kabir, R., Nguyen, T. T. (2008). Capital structure around the world: The roles of firm-and country-specific determinants. Journal of Banking \& Finance, 32(9), 1954-1969. DOI: 10.1016/j.jbankfin.2007.12.034

Fama, E. F., French, K. R. (2005). Financing decisions: who issues stock?. Journal of financial economics, 76(3), 549-582. DOI: 10.1016/j.jfineco.2004.10.003

Harris, M., Raviv, A. (1991). The theory of capital structure. the Journal of Finance, 46(1), 297-355. DOI: 10.2307/2328697

Hausman, J. (1978). Specification tests in econometrics. Econometrica, 46(6), 1251-1271. doi:10.2307/1913827 DOI: 10.2307/1913827

Hovakimian, A. (2004). The role of target leverage in security issues and repurchases. The Journal of Business, 77(4), 1041-1072. DOI: $10.1086 / 422442$

Jensen, M. C. (1986). Agency costs of free-cash-flow, corporate finance, and takeovers. American Economic Review 76, 323-329. DOI: $10.2139 /$ ssrn. 99580

Kayhan, A., Titman, S. (2007). Firms' histories and their capital structures. Journal of financial Economics, 83(1), 1-32. DOI: 10.1016/j.jfineco.2005.10.007

Kumar, S., Colombage, S., Rao, P. (2017). Research on capital structure determinants: a review and future directions. International Journal of Managerial Finance, 13(2), 106-132. DOI: 10.1108/IJMF-09-2014-0135

Loughran, T., Ritter, J. R. (1995). The new issues puzzle. The Journal of finance, 50(1), 23-51.

Miller, M. H. (1977). Debt and taxes. The Journal of Finance, 32(2), 261-275. DOI: 10.1111/j.1540-6261.1977.tb03267.x

Modigliani, F., Miller, M. H. (1958). The cost of capital, corporation finance and the theory of investment. The American Economic Review, 48(3), 261-297.

Modigliani, F., Miller, M. H. (1963). Income taxes and the cost of capital: a correction. The American Economic Review, 53(3), $433-443$.

Myers, S. C. (1977). Determinants of corporate borrowing. Journal of financial economics, 5(2), 147-175. DOI: 10.1016/0304-405X(77)90015-0

Myers, S. C. (1984). Capital structure puzzle. The Journal of Finance, 39(3), 575-592. DOI: 10.1111/j.1745-6622.1993.tb00369.x

Myers, S. C. (2003). Financing of corporations. In Handbook of the Economics of Finance (Vol. 1, pp. 215-253). Elsevier. DOI: 10.1016/S15740102(03)01008-2

Myers, S. C., Majluf, N. S. (1984). Corporate financing and investment decisions when firms have information that investors do not have. Journal of Financial Economics, 13(2), 187-221. DOI: 10.1016/0304-405X(84)90023-0

Oliver, B. R. (2005). The impact of management confidence on capital structure. DOI: 10.2139/ssrn.791924

Oliver, B. R., Mefteh, S. (2010). Capital structure choice: the influence of sentiment in France. International Journal of Behavioural Accounting and Finance, 1(4), 294-311. DOI: 10.1504/IJBAF.2010.032844

Ritter, J. R. (1991). The long-run performance of initial public offerings. The journal of finance, 46(1), 3-27. DOI: 10.1111/j.15406261.1991.tb03743.x

Shefrin, H. (2008). A behavioral approach to asset pricing. Elsevier.

Statman, M., Fisher, K. L., Anginer, D. (2008). Affect in a behavioral asset-pricing model. Financial Analysts Journal, 20-29. DOI: $10.2139 /$ ssrn. 1094070

Turkish Statistical Institute. Retrieved 2018, June 11 from http://www.turkstat.gov.tr/UstMenu.do?metod=temelist

Titman, S., Wessels, R. (1988). The determinants of capital structure choice. The Journal of finance, 43(1), 1-19. DOI: 10.1111/j.15406261.1988.tb02585.x 